\title{
Diagnostic Value of Procalcitonin Levels in Acute Mesenteric Ischemia
}

\author{
Yunus Karaca ${ }^{1}$, Abdulkadir Gündüz $^{1}$, Süha Türkmen ${ }^{1}$, Ahmet Menteşe $^{2}$, Süleyman Türedi ${ }^{1}$, \\ Umut Eryiğit ${ }^{3}$, Süleyman Caner Karahan ${ }^{2}$
}
'Department of Emergency Medicine, Karadeniz Technical University Faculty of Medicine, Trabzon, Turkey
${ }^{2}$ Department of Biochemistry, Karadeniz Technical University Faculty of Medicine, Trabzon, Turkey
${ }^{3}$ Department of Emergency Medicine, Diyarbakır Selahaddin Eyyubi State Hospital, Diyarbakır, Turkey

Background: Acute mesenteric ischemia (AMI) is a potentially fatal disease. Difficulties in diagnosis make it essential to find early biomarkers.

Aims: This study investigated the diagnostic value of procalcitonin (PCT) levels in AMI.

Study Design: Animal experimentation.

Methods: Rats were divided into six groups of six animals each. In the experimental group, an experimental ischemia model was established by clamping the superior mesenteric artery from the aortic outflow tract. Blood and tissue specimens were collected from rats in the experimental mesenteric ischemia model at $30 \mathrm{~min}$ and 2 and $6 \mathrm{~h}$, and these were compared with specimens from the respective control groups. PCT levels were compared at $30 \mathrm{~min}$ and 2 and $6 \mathrm{~h}$.
Results: PCT levels were $185.3 \mathrm{pg} / \mathrm{mL}$ in the control group and $219.3 \mathrm{pg} / \mathrm{mL}$ in the study group, $199.6 \mathrm{pg} /$ $\mathrm{mL}$ in the control group and $243.9 \mathrm{pg} / \mathrm{mL}$ in the study group, and $201.9 \mathrm{pg} / \mathrm{mL}$ in the control group and 286.9 $\mathrm{pg} / \mathrm{mL}$ in the study group, respectively, at 30 minute, 2 and 6 hours. Significant differences were determined between 6-h control group and ischemia group PCT levels $(\mathrm{p}=0.005)$.

Conclusion: The absence of a significant increase in PCT levels in the early period, while a significant difference was detected in the later period $(6 \mathrm{~h})$, shows that PCT levels rise late in mesenteric ischemia and can be a marker in the late period.

Keywords: Mesenteric ischemia, procalcitonin, intestinal ischemia
Acute mesenteric ischemia (AMI) is a rare condition, but one that frequently involves high mortality $(60 \%-80 \%)(1)$. Although it has different etiological causes, common outcomes of mesenteric ischemia are intestinal necrosis and gangrene (2). The most important factor determining mortality is early diagnosis and early surgical intervention. Laboratory findings in the early period are non-specific. Biomarkers to serve as guides in diagnosis are therefore needed (3).

Abdominal sepsis develops following inflammation arising from post-mesenteric ischemia and subsequent bacterial translocation. Procalcitonin (PCT) is a molecule consisting of 116 amino acids and with a molecular weight of 12793 Daltons. It plays a proinflammatory cytokine-like role and its levels rise in severe bacterial, fungal and parasitical infections, autoimmune diseases, sepsis and multiorgan failure (4). It is a biomarker used in the diagnosis of sepsis in the early period (5). PCT has been shown to begin to rise in the first $4 \mathrm{~h}$, reach a peak in 6-8 $\mathrm{h}$ and remain high for $24 \mathrm{~h}(6,7)$.

This experimental study was intended to evaluate changes in PCT levels from intestinal segments exposed to different periods of ischemia in an experimentally induced ischemia model. It was also intended to determine the PCT levels in mesenteric ischemia and to examine the relations between PCT levels and lactate and histological scores. 


\section{MATERIALS AND METHODS}

The study was initiated once ethical committee approval had been obtained. Thirty-six Sprague Dawley rats weighing 250$300 \mathrm{~g}$ were randomly divided into six groups of six animals each.

The standard experimental animals were kept under laboratory conditions. Following a $12 \mathrm{~h}$ fasting period, general anesthesia was performed with intramuscular administration of 50 $\mathrm{mg} / \mathrm{kg}$ ketamine and $5 \mathrm{mg} / \mathrm{kg}$ xylazine. All rats were cannulated with a $24 \mathrm{G}$ venous cannula from the left femoral vein and infused with $4 \mathrm{~mL} / \mathrm{kg}$ saline. Mesenteric ischemia was established in the study group by clamping the superior mesenteric arteries (SMAs) from the aortic outflow site. Blood and tissue specimens were collected after $30 \mathrm{~min}, 2$ and 6 hours. Laparotomy alone was performed on the rats in the control groups, and blood and tissue specimens were collected at the same intervals and then examined. Blood specimens were taken from the abdominal aorta and placed into tubes containing citrate. Tubes were centrifuged for $15 \mathrm{~min}$ at $1000 \mathrm{rpm}$, and plasma PCT and lactate levels in the separated sera were measured. PCT and lactate levels were determined for each group and compared using macro- and microscopic tissue examination.

Ileum segments $1 \mathrm{~cm}$ in length were taken from all study groups and examined histopathologically in order to determine ischemia-related changes. Injury in the preparations obtained was evaluated under a light microscope by a histologist blinded to the study groups.

Procalcitonin levels were determined using enzyme-linked immunosorbent assay (ELISA) kits (USCN Life Science Inc. Wurhan, P.R. China) following the manufacturer's recommendations. Specimen absorbances were measured using a VERSA max tunable microplate reader (Designed by Molecular Devices in California, USA) at a wavelength of $450 \mathrm{~nm}$. Lactate levels were measured using a Roche Vitros autoanalyzer at the Karadeniz Technical University Faculty of Medicine's Farabi Hospital Biochemistry Laboratory.

\section{Statistical analysis}

The control laparotomy groups and ischemia groups were analyzed separately. SPSS 13 for Windows (SPSS Inc., Chicago, IL, USA) was used to analyse all data obtained in the study.
These groups' PCT and lactate levels were investigated using Kruskal Wallis analysis of variance (Bonferroni corrected Mann-Whitney U test). All ischemia groups were compared with their corresponding control groups in terms of the same parameters using the Mann-Whitney $U$ test. $p<0.05$ was regarded as statistically significant.

\section{RESULTS}

\section{Biochemical analyses}

Mean biochemical values determined in all groups in the mesenteric ischemia model established are shown in Table 1. When biochemical parameters were compared between the ischemia and control groups for the same periods, significant differences in lactate levels were only determined between the 2-h control and ischemia groups and in PCT levels between the 6 - $h$ ischemia and control groups $(p=0.017$ for lactate; $\mathrm{p}=0.005$ for PCT). No significant difference was determined in other comparisons ( $\mathrm{p}>0.05$ for all periods and comparisons).

Time-dependent changes in biochemical parameters calculated from intra-group analysis of the ischemia and control groups were not significant ( $\mathrm{p}>0.05$ for all parameters).

\section{Histopathological evaluation}

According to the experimental protocol, once blood specimens had been collected at the end of the specified intervals, the rats were sacrificed and intestinal/ileum tissues evaluated under light microscopy. Upon light microscopic examination, various changes increasing over time were observed in the mucosa and submucosa in the control groups administered laparotomy alone (Figure 1a-c). Figure 1a shows a normal histological architecture, Figure 1b shows mild leukocyte infiltration and Figure 1c reveals a leukocyte and occasional villus conglomeration.

Increasing time-dependent changes were observed in the ischemia groups in which SMA occlusion was established. Mild leukocyte infiltration, villus conglomeration and hemorrhage within villi were observed in the 30-min group (Figure 2a). Widespread leukocyte infiltration, hemorrhage and villus degeneration were present in the 2- and 6-h groups (Figure 2b, c).

TABLE 1. Procalcitonin and lactate values compared by group

\begin{tabular}{|c|c|c|c|c|c|c|}
\hline \multirow{2}{*}{$\begin{array}{l}\text { Time } \\
\text { Parameter }\end{array}$} & \multicolumn{2}{|c|}{$30 \mathrm{~min}$} & \multicolumn{2}{|c|}{$2 \mathrm{~h}$} & \multicolumn{2}{|c|}{$6 \mathrm{~h}$} \\
\hline & Group 1 & Group 2 & Group 3 & Group 4 & Group 5 & Group 6 \\
\hline Procalcitonin $(\mathrm{pg} / \mathrm{mL})$ & 185.3 & 219.3 & 199.6 & 243.9 & 201.9 & $286.9^{*}$ \\
\hline Lactate (mg/dL) & 12.2 & 13.7 & 10.3 & $19.1^{*}$ & 20.1 & 20.4 \\
\hline
\end{tabular}



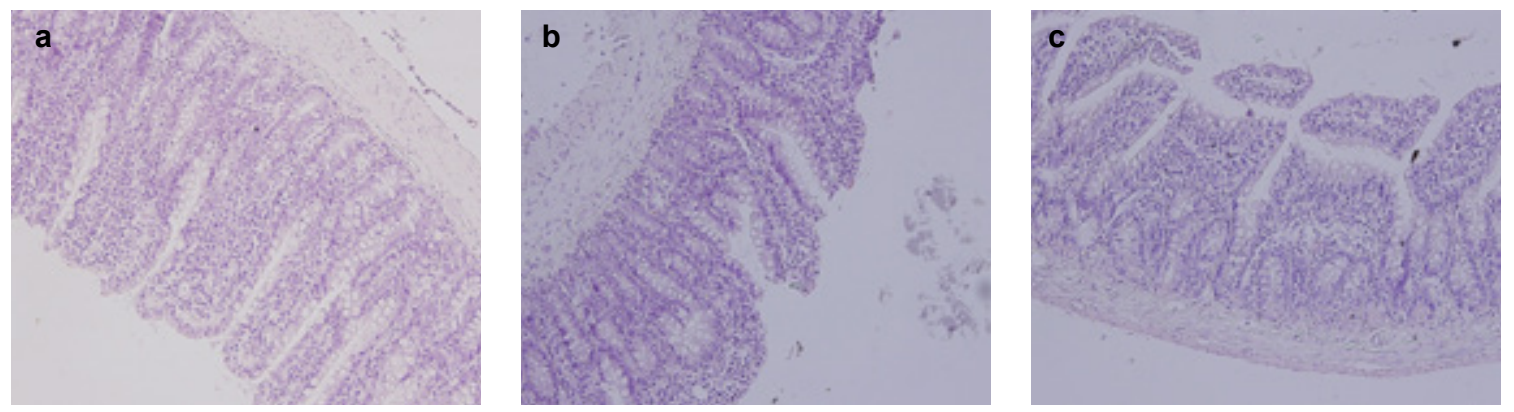

FIG. 1. a-c. A normal histological architecture (a), mild leukocyte infiltration (b), a leukocyte and occasional villus conglomeration (c) (HE x 200)
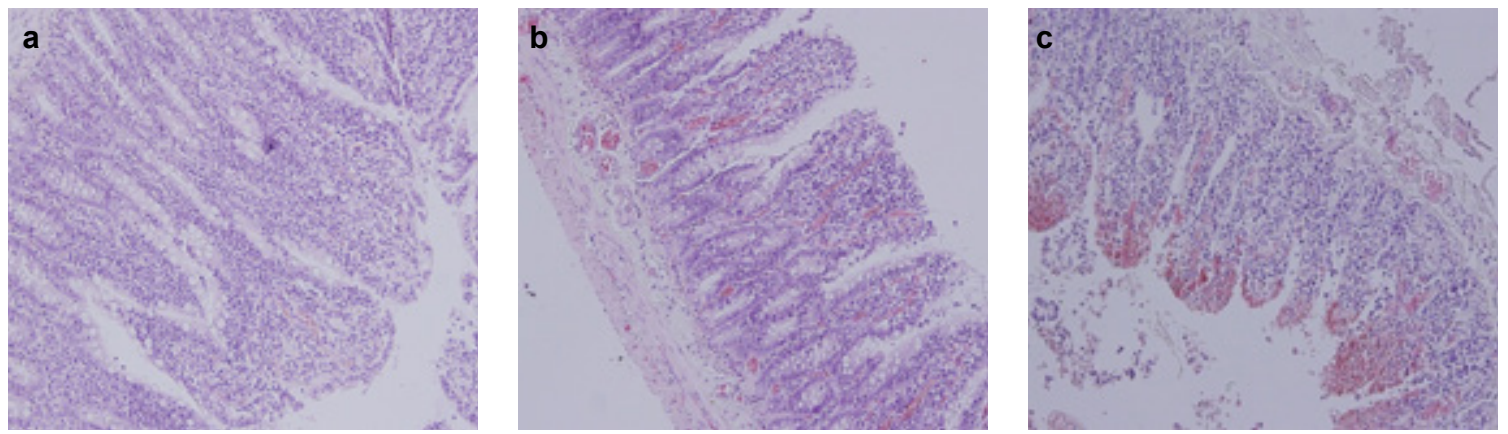

FIG. 2. a-c. Mild leukocyte infiltration, villus conglomeration and hemorrhage within villi in the 30-min group (a), widespread leukocyte infiltration, hemorrhage and villus degeneration in the 2-h and 6-h groups (b, c) (HE x 200)

Histopathological damage scores determined in the groups are shown in Table 2. Comparison of histopathological damage between the control and ischemia groups for the same time periods revealed significantly greater injury in the ischemic groups ( $\mathrm{p}=0.009$ for $30 \mathrm{~min}, \mathrm{p}=0.04$ for $2 \mathrm{~h}, \mathrm{p}=0.001$ for $6 \mathrm{~h}$ ).

Results of the analysis of correlations of the parameters evaluated in this study are shown in Table 3 . When the correlation between parameters was examined, only lactate levels and histopathological damage scores were significantly positively correlated.

\section{DISCUSSION}

Various biochemical markers have been investigated for the diagnosis of AMI, but no sufficiently reliable marker has yet been identified. Several parameters have been studied for diagnosis of AMI, such as whole blood count and white cell counts, organic-inorganic phosphate, lactate dehydrogenase (LDH), amylase, acid phosphatase, alkaline phosphatase, creatinine phosphokinase, lactate, alanine transaminase (ALT), aspartate transaminase (AST), D-dimer, peritoneal $\mathrm{pH}$ measurement, nitric oxide, blood and peritoneal potassium levels, lipase and intestinal fatty acid binding protein (I-FABP), but none have entered into clinical use (9). D-lactate is a product of bacterial fermentation. It is produced by microflora in the ischemic intes- tinal flora and enters the circulation in association with impairment of the mucosal barrier. In one study by Lange et al. (10), lactate was $100 \%$ sensitive as a marker for AMI, but only $42 \%$ specific. In an experimental study by Kulaçoğlu et al. (11), a significant increase in plasma lactate levels was determined in the mesenteric ischemia induction group. Another study concluded that serum lactate measurement was useful for diagnostic purposes but could only be confirmatory (12). In our study, lactate levels only rose in a statistically significant manner between the 2-h mesenteric ischemia group and the corresponding control group. This finding is compatible with data from the literature suggesting that lactate levels can be used in the diagnosis of AMI, particularly in the early periods.

D-dimer is a marker that has been much investigated in recent years. Several studies have shown that D-dimer may be an effective parameter in the diagnosis of AMI. One study in particular, by Acosta et al. (13), reported D-dimer sensitivity of $100 \%$ and specificity of $36 \%$. Experimental studies on rats by Altınyollar and Kurt showed that d-dimer levels rise following ischemia $(14,15)$.

In a recent experimental study involving AMI, Rau et al. (16) compared MDA, lactate and ischemia modified albumin levels and determined that variables measured at $30 \mathrm{~min}$ and 2 and $6 \mathrm{~h}$ were higher in the ischemia group compared to the control group for all parameters. We determined a similar finding for 2-h lactate levels in our study as this study. 
TABLE 2. Histopathological damage scores of groups

\begin{tabular}{|c|c|c|c|c|c|c|}
\hline & \multicolumn{6}{|c|}{ Time } \\
\hline & \multicolumn{2}{|c|}{30 minute } & \multicolumn{2}{|c|}{2 hour } & \multicolumn{2}{|c|}{6 hour } \\
\hline & Group 1 & Group 2 & Group 3 & Group 4 & Group 5 & Group 6 \\
\hline $\begin{array}{l}\text { Total Histopathological } \\
\text { Damage Score }\end{array}$ & $1.5 \pm 1.36$ & $6.0 \pm 2.50$ & $3.5 \pm 1.50$ & $9.0 \pm 3.84$ & $5.0 \pm 1.57$ & $12.0 \pm 1.03$ \\
\hline
\end{tabular}

TABLE 3. Correlation of biochemical and histopathological score parameters

\begin{tabular}{lccccc}
\hline & \multicolumn{2}{c}{ Lactate } & & \multicolumn{2}{c}{$\begin{array}{c}\text { Histopathological } \\
\text { Damage Score }\end{array}$} \\
\cline { 2 - 3 } \cline { 6 - 7 } & $\mathrm{r}$ & $\mathrm{p}$ & & $\mathrm{r}$ & $\mathrm{p}$ \\
\hline Procalcitonin & -0.136 & 0.430 & & 0.285 & 0.092 \\
Lactate & & & & 0.509 & 0.002
\end{tabular}

Procalcitonin is a novel biomarker that is used for infectious conditions. It plays a proinflammatory cytokinelike role and its levels rise in severe bacterial, fungal and parasitical infections, autoimmune diseases, sepsis and multiorgan failure (4) It has been found that PCT levels rise earlier than C-reactive protein (CRP) and white blood cells in sepsis and infectious diseases (17). PCT levels can be detectable after 2-3 hours of infection, increase rapidly in 6-8 hours and reach a peak value in 12 hours (18). Several studies have shown that PCT can be used in early and differential diagnosis of bacterial sepsis, and a sensitivity of $60 \%-100 \%$ and specificity of $79 \%-100 \%$ have been reported. Güven et al. (19) reported that PCT, found to be more specific than $\mathrm{C}$-reactive protein in the diagnosis of bacterial sepsis, can be used in the early diagnosis of bacterial infections in emergency departments. Steinwald et al. (20) reported that PCT levels can be used as a marker for the degree of sepsis and mortality. In a study investigating whether PCT levels can be used in the early diagnosis of AMI in an experimental AMI model, Karabulut et al. (21) reported that PCT levels rise in the early period in AMI and can be used as a diagnostic and prognostic marker.

In conclusion, our study is one of the first in the literature to evaluate PCT levels in AMI, and is therefore original. Bearing in mind the bacterial translocation and tendency to sepsis that take place in AMI patients, although PCT levels rise in AMI patients and we think that this elevation can be diagnostically useful, PCT levels have been proven to rise significantly only in the late periods of experimentally induced mesenteric ischemia. The absence of any significant increase in the first $2 \mathrm{~h}$, regarded as a critical period for early diagnosis, suggests that PCT levels are not suitable for use in early diagnosis. Significant differences in the later period $\left(6^{\text {th }} \mathrm{h}\right)$ shows that PCT levels rise in the late period in mesenteric ischemia and can be a marker in the late period.
Ethics Committee Approval: Ethics committee approval was received for this study from the Ethics Committee of Karadeniz Technical University Faculty of Medicine (Protocol No: 2009-4).

Informed Consent: Experimental study.

Peer-review: Externally peer-reviewed.

Author contributions: Concept - A.G., S.T., Y.K.; Design - A.G., S.T., S.T.; Supervision - A.G., Y.K., S.T., S.T.; Resource - Y.K., U.E., A.M.; Materials - A.,M., S.T., S.C.K.; Data Collection \&/or Processing - Y.K., S.T., S.T., A.M.; Analysis \&/or Interpretation S.T., S.T., A.G., S.C.K.; Literature Search - S.T., Y.K., U.E.; Writing - Y.K., U.E., S.T.; Critical Reviews - A.G., S.C.K., S.T., S.T., Y.K., A.M., U.E.

Conflict of Interest: No conflict of interest was declared by the authors.

Financial Disclosure: The authors declared that this study has received no financial support.

\section{REFERENCES}

1. Menon NJ, Amin AM, Mohammed A, Hamilton G. Acute mesenteric ischaemia. Acta Chir Belg 2005;105:344-54.

2. Yasuhara H. Acute mesenteric ischemia: the challenge of gastroenterology. Surg Today 2005;35:185-95. [CrossRef]

3. Christopher MB. Fernandes Mesenteric Ischemia. http://www. emedicine.com/EMERG/topic311.htm. Accessed: 13.09.2006.

4. Carrol ED, Thomson AP, Hart CA. Procalcitonin as a marker of sepsis. Int J Antimicrob Agents 2002;20:1-9. [CrossRef]

5. Massaro KS, Costa SF, Leone C, Chamone DA. Procalcitonin (PCT) and C-reactive protein (CRP) as severe systemic infection markers in febrile neutropenic adults. BMC Infect Dis 2000;7:137. [CrossRef]

6. Burtis CA, Ashwood ER. Klinik Kimyada Temel İlkeler. Palme Yayınları, 5th Ed. Ankara, 2005, p. 450-2.

7. Assicat M, Gendrel D, Carsin H, Raymond J, Guilbaud J, Bohuon C. High serum procalcitonin concentrations in patients with sepsis and infections. Lancet 1993;341:515-8. [CrossRef]

8. Yasuhara H. Acute mesenteric ischemia: the challenge of gastroenterology. Surg Today 2005;35:185-95. [CrossRef] 
9. Kozuch PL, Brandt LJ. Review article: diagnosis and management of mesenteric ischaemia with an emphasis on pharmacotherapy. Aliment Pharmacol Ther 2005;21:201-15. [CrossRef]

10. Lange H, Jackel R. Usefulness of plasma lactate concentration in the diagnosis of acute abdominal disease. Eur J Surg 1994;160:381-4.

11. Kulaçoğlu H, Kocaerkek Z, Moran M, Kulah B, Atay Ç, Kulaçoğlu S. Diagnostic value of blood D-dimer level in acute mesenteric ischaemia in the rat: An experimental study. Asian $J$ Surg 2005;28:131-5. [CrossRef]

12. Meyer T, Klein P, Schweiger H, Lang W. How can the prognosis of acute mesenteric artery ischemia be improved? Results of a retrospektive analysis. Zentralbl Chir 1998;123:230-4.

13. Acosta S, Ogren M, Sternby NH, Bergqvist D, Bjorck M. Clinical implications for the management of acute thromboembolic occlusion of the superior mesenteric artery: autopsy findings in 213 patients. Ann Surg 2005;241:516-22. [CrossRef]

14. Altinyollar H, Boyabatli M, Berberoglu U. D-dimer as a marker for early diagnosis of acute mesenteric ischemia. Thromb Res 2006;117:463-7. [CrossRef]

15. Kurt Y, Akin ML, Demirbas S, Uluutku AH, Gulderen M, Avsar $\mathrm{K}$, Celenk T. D-dimer in the early diagnosis of acute mesenteric ischemia secondary to arterial occlusion in rats. Eur Surg Res 2005;37:216-9. [CrossRef]

16. Rau B, Steinbech G, Baum gart K, Gansauge F, Beger HG. The clinical value of procalcitonin in the prediction of infected necrosis in acute pancreatitis. Intensive Care Med 2000;26:159-64. [CrossRef]

17. Meisner M. Pathobiochemistry and clinical use of procalcitonin. Clin Chim Acta 2002;323:17-29. [CrossRef]

18. Becker KL, Nylen ES, Cohen R, Snider RH. Calcitonin: Structure, molecular biology, and actions. Principles of Bone Biology. Academic Press Inc.; 1996. p. 471-4.

19. Guven H, Altıntop L, Baydın A, Esen S. Diagnostic value of procalcitonin levels as an early indicator of sepsis. Am J Emerg Med 2002;20:202-6. [CrossRef]

20. Steinwald PM, Whang KT, Becker KL, Snider RH, Nylen ES, White JC. Elevated calcitonin precursor levels are related to mortality in an animal model of sepsis. Crit Care 1999;3:11-6. [CrossRef] 21. Karabulut K, Gül M, Dündar ZD, Cander B, Kurban S, Toy H. Diagnostic and prognostic value of procalcitonin and phosphorus in acute mesenteric ischemia. Ulus Travma Acil Cerrahi Derg 2011;17:193-8. [CrossRef] 